\title{
ON THE FACTORS AFFECTING THE PRODUCTIVITY OF THE SOUTHERN MAKASSAR STRAIT
}

\author{
by \\ ABDUL GANI ILAHUDE ${ }^{1)}$ \\ (Manuscript received 23 April 1978)
}

\begin{abstract}
An investigation of the upwelling in the Southern Makassar Strait was conducted by LON (Lembaga Oseanologi Nasional) as part of its research program in ecology and oceanography of the Indonesian waters. It consists of observation on one monitoring station and two oceanographical cruises in the region.

The result of the monitoring station indicates clearly the occurrence of upwelling and its effect on the hydrology of the region. During the southeast monsoon the upwelled water causes a decrease in temperature and dissolved oxygen and an increase in salinity, density and nitrate-nitrogen, particularly seen at the lower boundary of the homogeneous layer. During the northwest monsoon the upwelled water is replaced by the Jawa Sea water with high temperature, low oxygen, low salinity, low density, very high phosphate, and high silicate.

The observation on the oceanographical cruises reveals the precence of two other types of surface waters in the region. They are the East Kalimantan Coastal Water and the South Sulawesi Coastal Water, each is formed by mixing process of sea water and land drainage along the coast of the two islands respectively. Originally they are characterized by low salinity, low oxygen, high temperature, high phosphate, low nitrate and high silicate. Their salinity and dissolved oxygen increase due to mixing with the upwelled water and the high activity of phytoplankton respectively.
\end{abstract}

\section{IKHTISAR}

Sebuah penelitian tentang penaikan air di Selat Makassar bagian selatan telah dilaksanakan LON (Lembaga Oseanologi Nasional) sebagai bagian program risetnya di bidang ekologi dan oseanografi perairan Indonesia. Penelitian tersebut terdiri atas pengamatan pada sebuah setasiun pemonitoran dan dua pelayaran oseanografi di wilayah itu.

Hasil setasiun pemonitoran menunjukkan dengan jelas terjadinya penaikan air dan akibatnya atas hidrologi wilayah ini. Pada musim tenggara air yang naik menyebabkan penurunan suhu dan oksigen terlarut dan peningkatan salinitas, kepada tari, dan nitrogen-nitrat, yang khusus terlihat pada sempadan bawah lapisan homogen. Pada musim baratlaut air yang naik tadi diganti oleh Tirta Laut Jawa yang bersuhu tinggi, oksigen rendah, salinitas rendah, kepadatan rendah, fosfat yang sangat tinggi, dan silikat yang juga tinggi.

Pengamatan pada pelayaran oseanografi menyingkapkan adanya dua jenis air permukaan yang lain di wilayah ini. Kedua air itu ialah Tirta Pantai Kalimantan Timur dan Tirta Pantai Sulawesi Selatan, masing-masing dibentuk oleh proses percampuran air laut dan aliran sungai sepanjang pantai ke dua pulau tersebut. Pada mulanya kedua jenis air ini dicirii oleh salinitas yang rendah, oksigen rendah, suhu tinggi, fosfat tinggi, nitrat rendah dan silikat yang tinggi. Kemudian salinitas dan kadar oksigennya

1) Contribution of the Lembaga Oseanologi Nasional — LIPI, Jakarta. 
meningkat, masing-masing disebabkan oleh percampuran dengan air yang naik dan oleh kegiatan fitoplankton yang tinggi.

\section{INTRODUCTION}

Upwelling is already know or suspected to occur as a major factor in a number of areas in Indonesian waters (BRODIE, 1976). One of these areas is the Southern Makassar Strait. The occurrence of upwelling in this region was first suspected by VEEN (1953), while working on the results of his surface salinity study in the Indonesian and adjacent waters. He found that the surface salinity in the region off the coast of Makassar in June and July showed often higher values than in the surrounding areas.

WYRTKI (1961) agreed with VEEN that this high surface salinity value could only be attributed to upwelling, since no connnection was visible between it and the waters of high salinity in the western Banda Sea or in the Indian Ocean. Ho ascribed the upwelling to the transport system in the region. During the southeast monsoon, water masses of the Flores Sea meet hero with water coming out of the Makassar Strait and flow together into the Jawa Sea. He believed that under these conditions it seems possible that immediately off the coast of Makassar, the water masses of the surface are integrated into this flow, and water from deeper layer ascends, even if only in small quantities.

Because of the importance of up welling in the productivity of the region, LON/Lembaga Oseanologi Nasional (formerly: LPL/Lembaga Penyelidikan Laut) carried out an oceanographical cruise to study the upwelling in the southern Makassar Strait. The result of this study has been reported by ILAHUDE (1970). Among his findings was that though the contribution of upwelling to the surface water was slight, it did influence the hydrological features of the area, including its productivity. Therefore he suggested that a thorough oceanographical observation in the Southern Makassar Strait be made to study the effect of upwelling on the productivity of the region. Ho also proposed that such study should include not only temperature and salinity, but also nutrients, plankton and light measurements.

To carry out the proposed study, LON (Lembaga Oseanologi Nasional) has made further oceanographical observations in the region. They consist of measurements on hydrological parameters, chlorophyll content, phytoplankton density and zooplankton density. The objective of the study is to investigate further the effect of upwelling on the hydrology of the region in general and its productivity in particular. The present report is based on the results of this study.

\section{MATERIALS AND METHODS}

Two sets of data were used in preparing this report. The first set of data was those obtained as the result of observations on a monitoring station at approximately $05^{\circ} 43.3^{\prime} \mathrm{S}$ latitude, 11850.8' E longitude, 


\section{PRODUCTIVITY OF MAKASSAR STRAIT}

southwest of South Sulawesi. The station was occupied repeatedly by LON's R.V. Samudera during her 1971 - 1976 oceanographical cruises in various Indonesian waters (Table I and Fig. 1). This station was previously occupied by the R.V. Jalanidhi in 1966 and its data were also used in the present study (Table I).

Assuming the seasonality of the hydrological conditions to be regular, the data were grouped according to their seasons into pre-upwelling period (March 1966 and March 1973), upwelling period (August 1971 and August 1974) and post-upwelling period (October 1972 and December 1976). Vertical cross-sections of temperature, salinity, density, dissolved oxygen and inorganic phosphate down to $400 \mathrm{~m}$ were constructed according to this grouping, regardless of the chronological sequences of the stations (Fig. 3 to 7). Following ILAHUDE (1970), correction of $-0.50 \mu \mathrm{g} \mathrm{A} \mathrm{PO}_{4}{ }^{-}$ $\mathrm{P} / \mathrm{l}$ was applied to the phosphate data of station No. 24, March 1966, Temperature and density $(\tau t)$ values at $150 \mathrm{~m}$ and $200 \mathrm{~m}$ depths of station No. 31, August 1971 and a salinity value at $145 \mathrm{~m}$ depth of station No. 9, August 1974 were disregarded because they do not conform with the rest of the data.

The second set of data used were those obtained during the two cruises of the R.V. Samudera in the region in August 1974 and May 1975 (Fig. 2). During each cruise 30 oceanographic stations were occupied, on which temperature, salinity, dissolved oxygen, inorganic phosphate, nitrate and silicate measurements at the surface and at $25-50 \mathrm{~m}$ depth, chlorophyll at the surface and at $25-50 \mathrm{~m}$ depth (May stations only) and phyto and zooplankton vertical hauls were carried out. Methods of hydrological measurements, chlorophyll determination and plankton density calculation were described in the reports of the cruises (INST. MAR. RES., 1974 and 1975). Out of these data, horizontal distribution of each hydrological parameter at $0 \mathrm{~m}$ (surface layer) and $25-50 \mathrm{~m}$ depth (subsurface layer) was prepared (Fig. 8 to 11). Similarly the horizontal distribution of surface chlorophyll at $0 \mathrm{~m}$, and distribution of phytoplankton and zooplankton density were also drawn (Fig. 12). Recalculation of the observed values of the plankton data to the $50 \mathrm{~m}$ base was made for the stations with hauls greater than $50 \mathrm{~m}$ depth, according to the assumption that the plankton were concentrated at the upper $50 \mathrm{~m}$ column. In this report, the unit adopted to indicate plankton density (settling volume for phytoplankton, displacement volume for zooplankton) is $\mathrm{ml} / \mathrm{m}^{3}$.

\section{a. Vertical distribution}

\section{RESULTS}

The important feature of temperature distribution to note is the presence of deep thermally homogeneous layer of $27.0-28.0^{\circ} \mathrm{C}$ down to $100 \mathrm{~m}$ during the pre-upwelling period of March 1966 and March 1973 


\section{A. G. ILAHUDE}

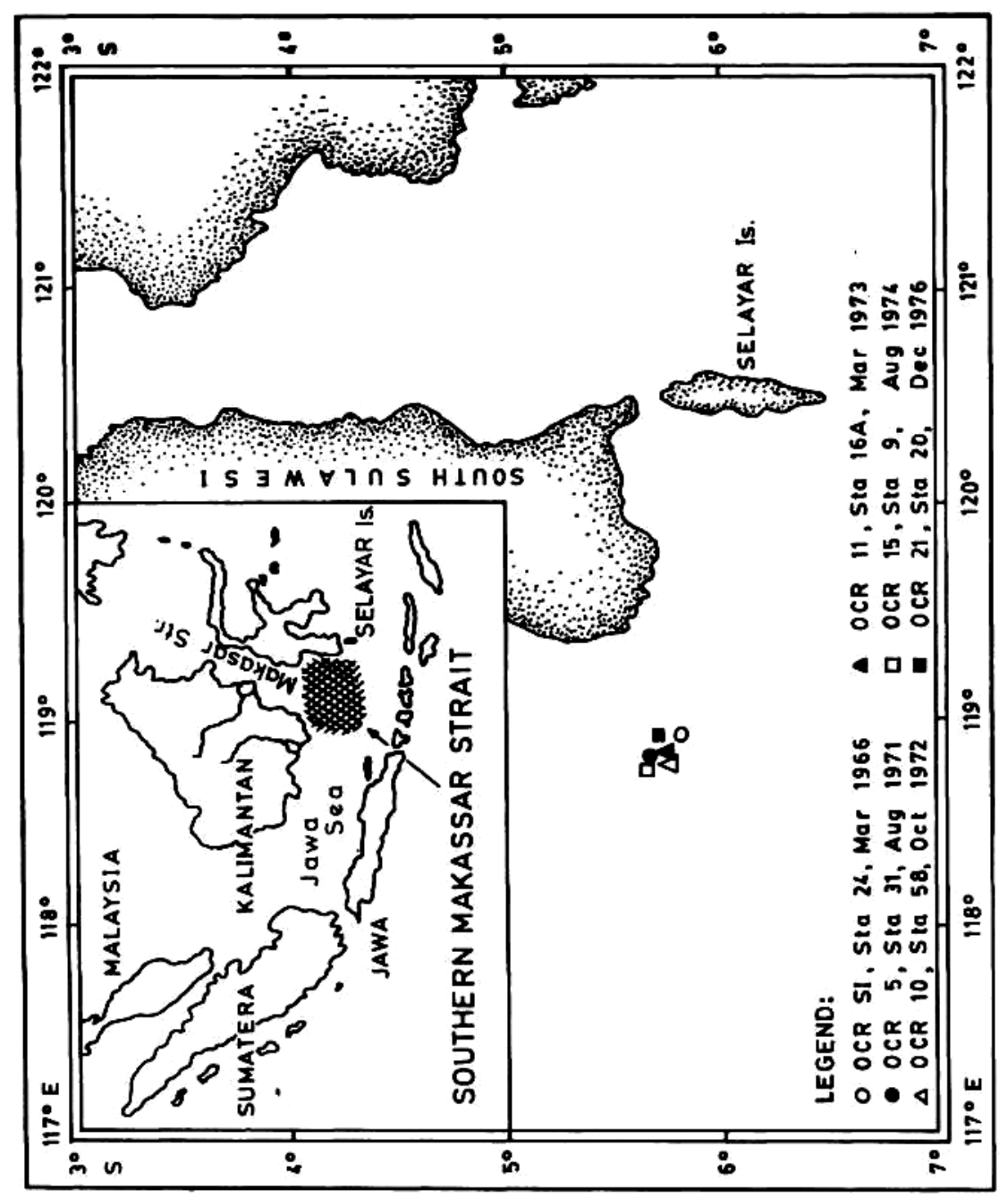

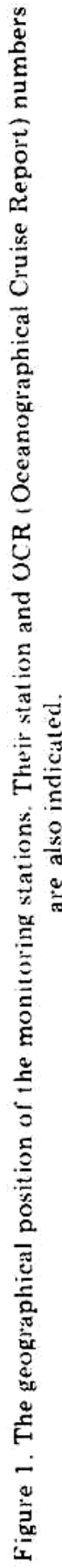


PRODUCTIVITY OF MAKASSAR STRAIT

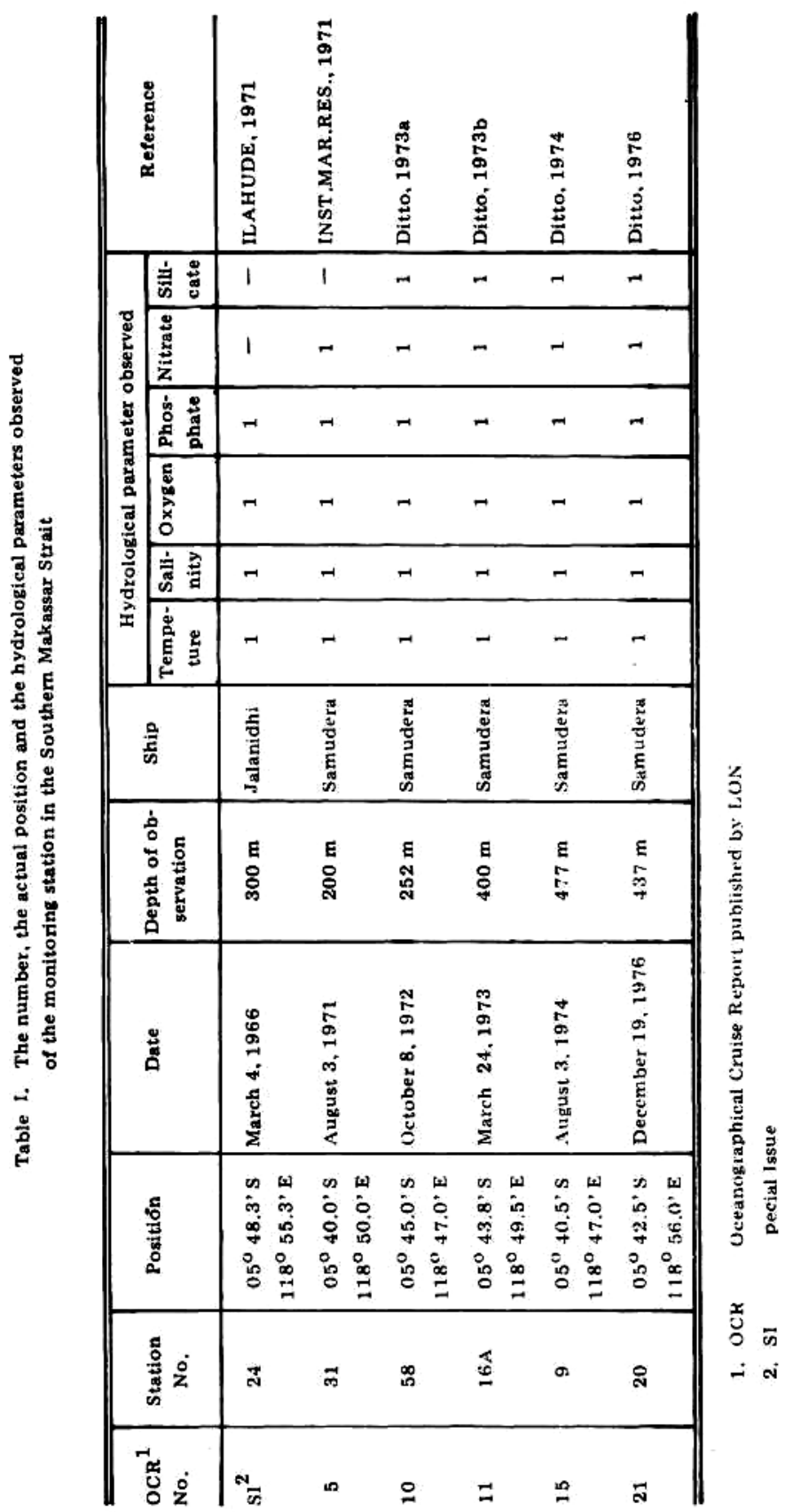




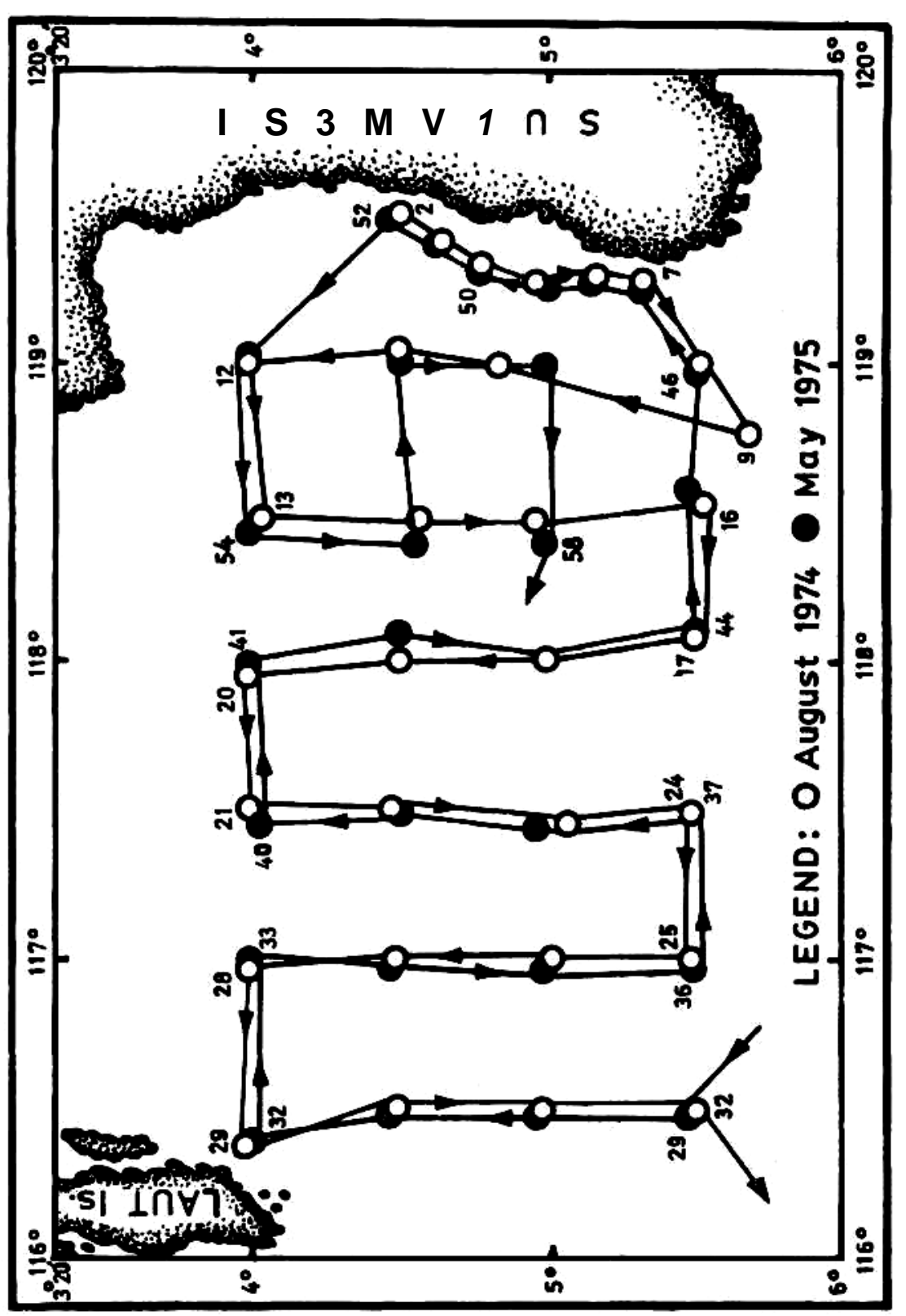

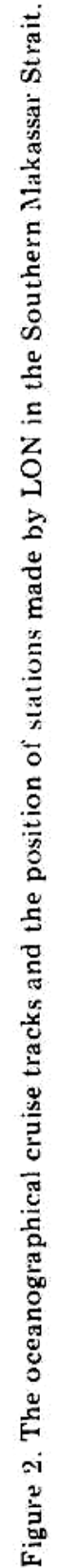




\section{PRODUCTIVITY OF MAKASSAR STRAIT}

(Fig. 3). A sharp and thin thermocline layer underlies the homogeneous layer, where the temperature decreases from $26.0^{\circ} \mathrm{C}$ at $100 \mathrm{~m}$ to $12.0^{\circ} \mathrm{C}$ at about $280 \mathrm{~m}$. Under the thermocline layer lies the cold water sphere where the temperature decreases gradually to about $9.2^{\circ} \mathrm{C}$ at $400 \mathrm{~m}$ depth.

During the upwelling period of August 1971 and August 1974, the thickness of the homogeneous layer decreases to $50 \mathrm{~m}$ deep. It consists of a colder water mass with a temperature of $26.0-27.0^{\circ} \mathrm{C}$. The upwelling produces a $50 \mathrm{~m}$ rise of the water mass as indicated by the $26.0^{\circ} \mathrm{C}$ isotherm, causing the thermocline layer to become thicker and less sharp. In the post-upwelling period of October 1972 and December 1976, the thickness of the homogeneous layer, as indicated by the $26.0^{\circ} \mathrm{C}$ isotherm, increases again down to $100 \mathrm{~m}$, causing the thermocline layer to become thinner and sharper. The lower boundary of the thermocline layer is the $12.0 \mathrm{C}$ isotherm at $280 \mathrm{~m}$ which remain relatively level throughout the year.

Jawa Sea Water of low salinity (32.5 - $34.0 \%$ o) occupies the upper part of the homogeneous layer during the pre-upwelling period (Fig. 4). It lies over the Northern Pacific Subtropical Lower Water of maximum salinity (greater than $34.6 \%$ ), at 150 to $250 \mathrm{~m}$. The Subtropical Lower Water in turn lies over the Northern Pacific Intermediate Water with minimum salinity (less than $34.52 \%$ ) at $400 \mathrm{~m}$. During the upwelling period, the Jawa Sea Water of low salinity is replaced by the upwelled high salinity Subtropical Lower Water. Because of the dry season that usually follows the upwelling period, the surface salinity in the early part of the postupwelling period can be higher than $34.5 \%$. However, the arrival of the Jawa Sea Water and the accompanying rainfall reduce the salinity to less than $34.0 \%$ in the later part of the post-upwelling period.

The low salinity Jawa Sea Water during the pre-upwelling period is characterized also by low density as indicated by low sigma-T (less than 21,0), low inorganic phosphate (less than $0.1 \mu \mathrm{g} \mathrm{A} / 1$ ) and relatively high dissolved oxygen (greater than $4.3 \mathrm{ml} / 1$ ). During the upwelling season the density increases to over 22.0, phosphate to over $0.1 \mu \mathrm{gA} / 1$ while the oxygen content decreases to below 4.3. $\mathrm{ml} / 1$, due primarily to the upwelled Subtropical Lower Water (Fig. 5, 6, and 7). In the post upwelling period the density and phosphate start to decrease and oxygen starts to increase to their values of the pre-upwelling period, with several notable deviations. The density in October 1972 remains above 22.0 before it decreases to less than 22.0 in December 1976. Oxygen increases in October 1972 but decreases again in December 1976. Phosphate decreases in October 1972 and increases in December 1976.

Below $100 \mathrm{~m}$, the maximum depth of the homogeneous layer, there is little seasonal change of hydrological properties of the water masses. Throughout the year the core layer of the Subtropical Lower Water is 
A. G. ILAHUDE

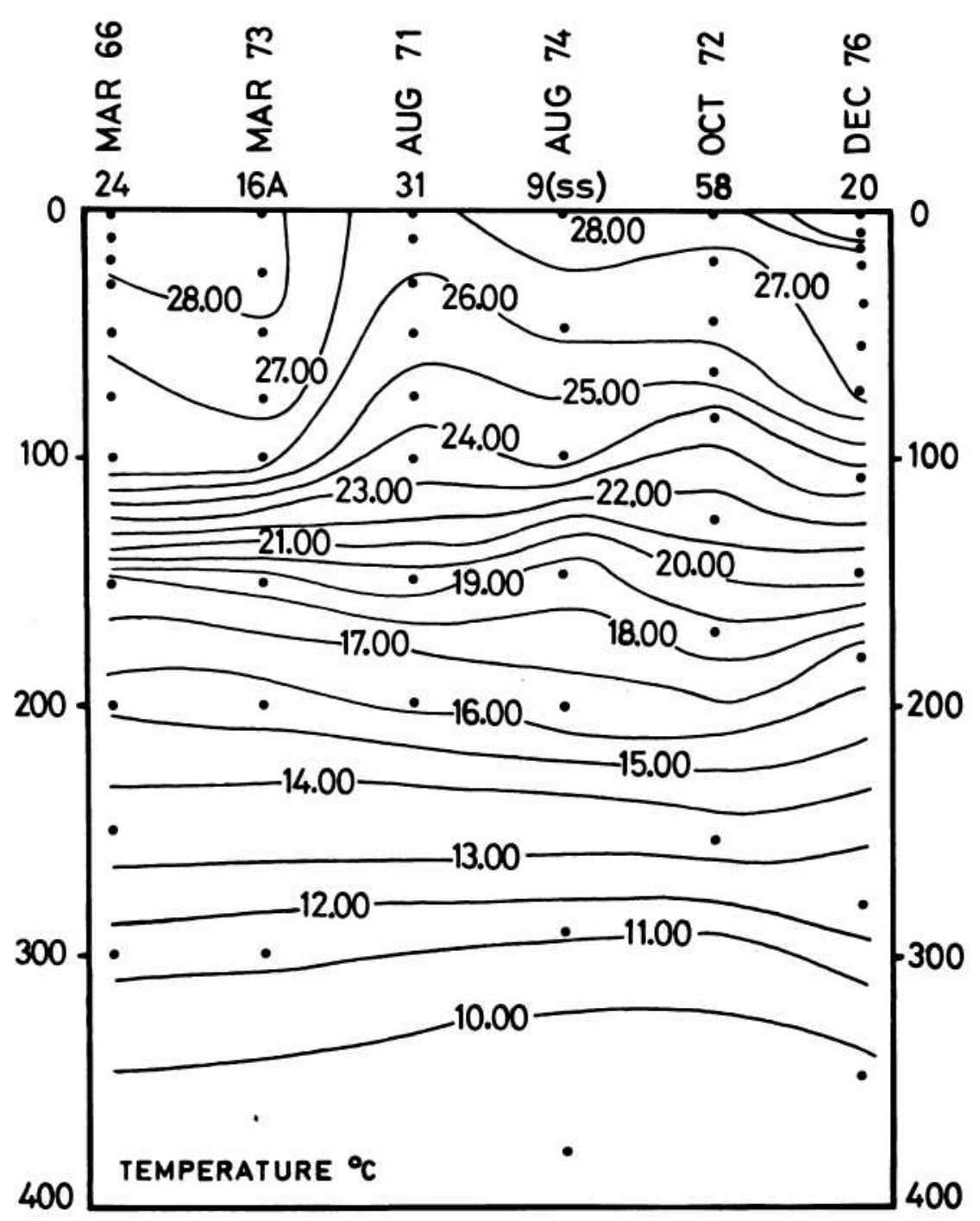

Figure 3. Cross section of temperature in the Southern Makassar Strait. The dots indicate the observation depths, the numbers and the months on the top side indicate the stations and the numbers on the side indicate the depths in meter. 
PRODUCTIVITY OF MAKASSAR STRAIT

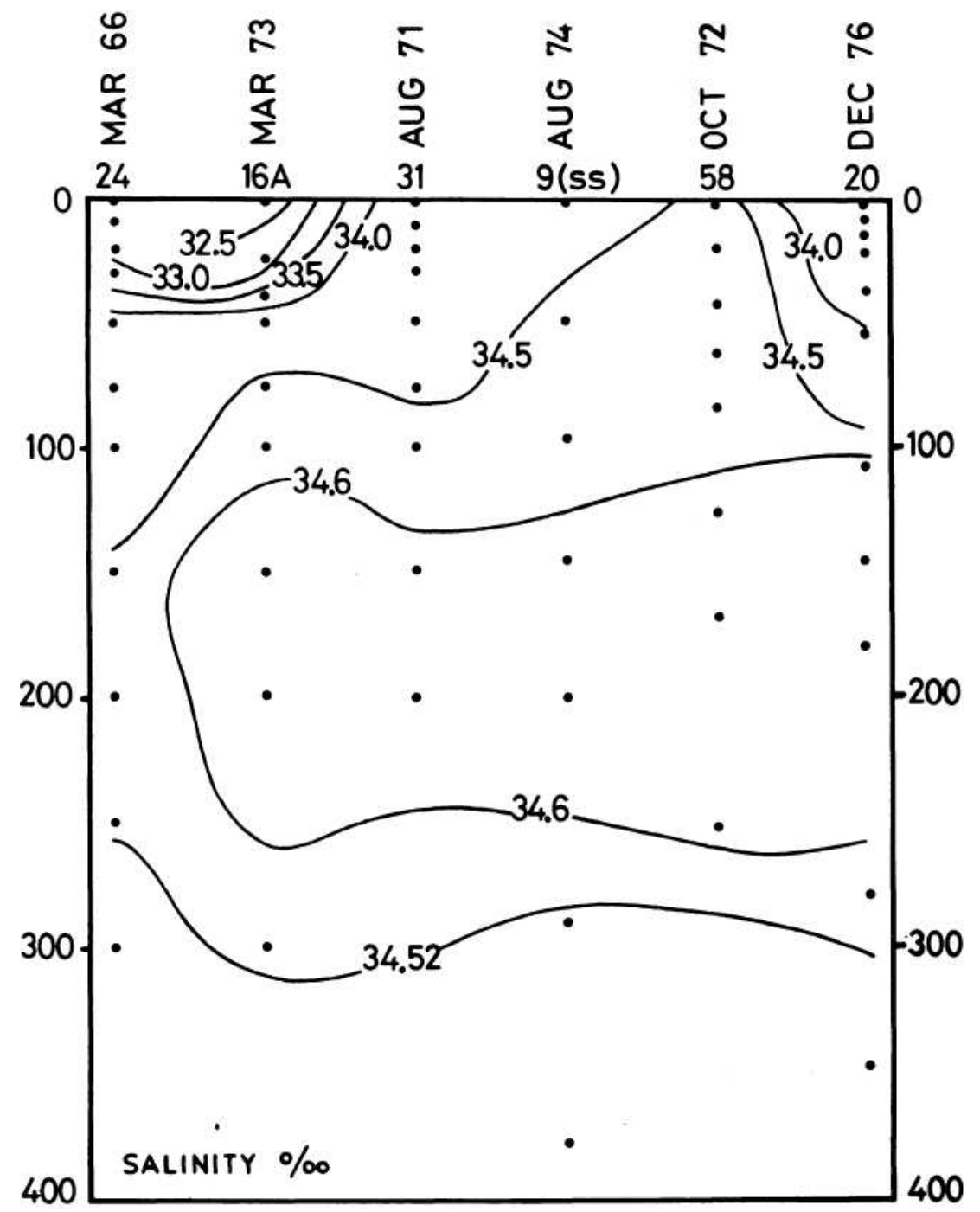

Figure 4. Cross section of salinity in the Southern Makassar Strait. Legend is as in Figure 3. 
A. G. ILAHUDE

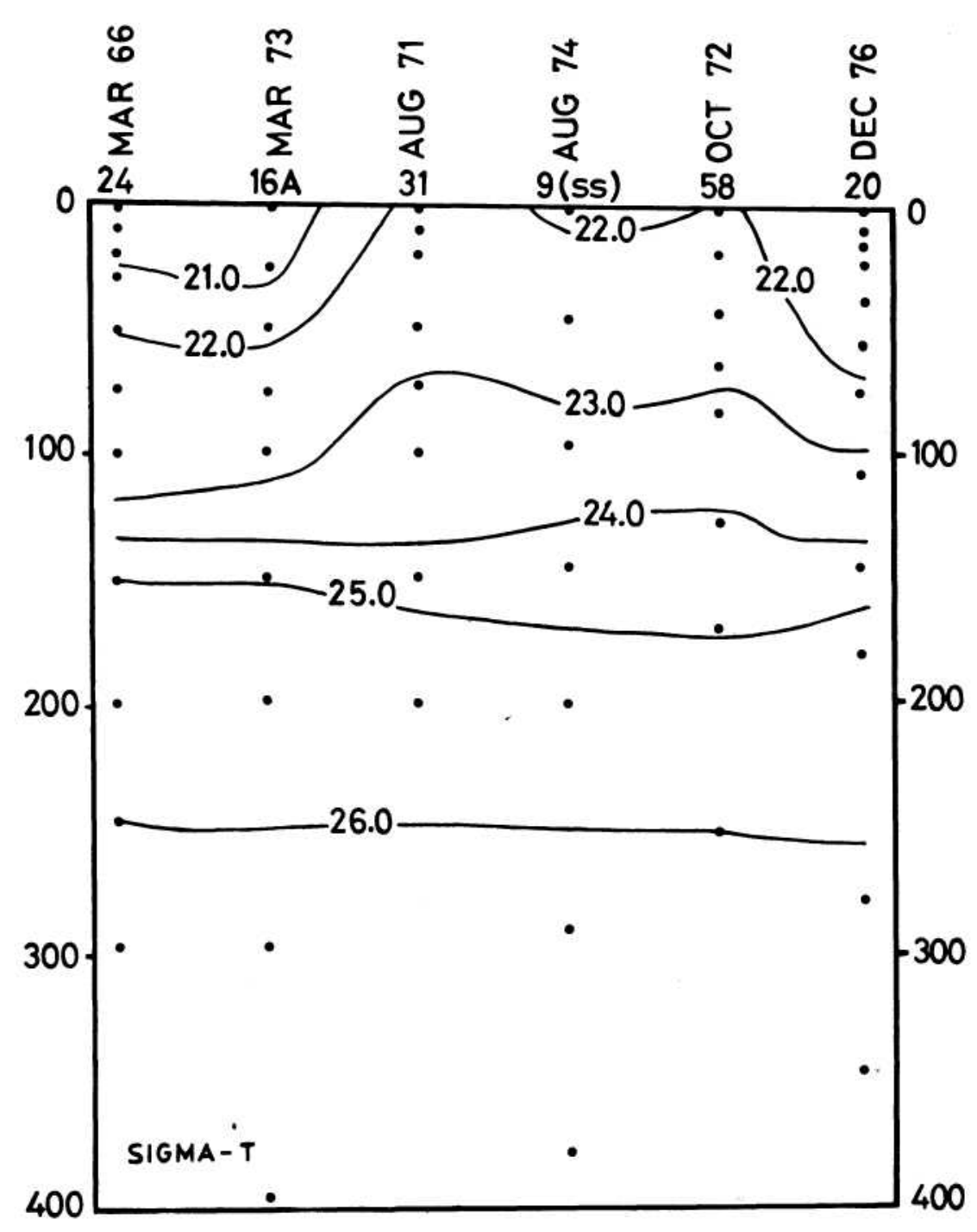

Figure 5. Cross section of density (Sigma-T) in the Southern Makassar Strait. Legend is as in Figure 3. 
PRODUCTIVITY OF MAKASSAR STRAIT

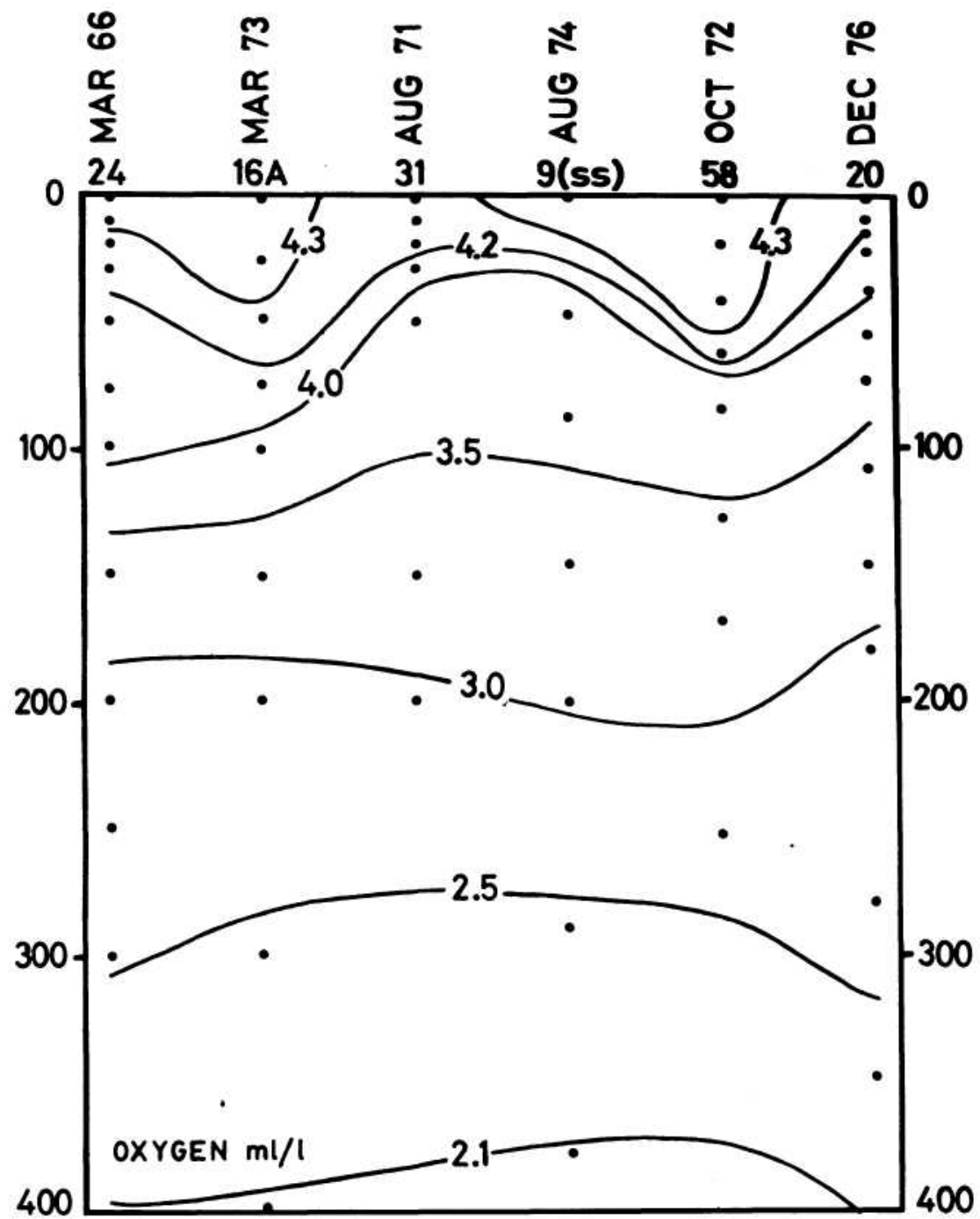

Figure 6. Cross section of dissolved oxygen in the Southern Makassar Strait. Legend is as in Figure 3. 
A. G. ILAHUDE

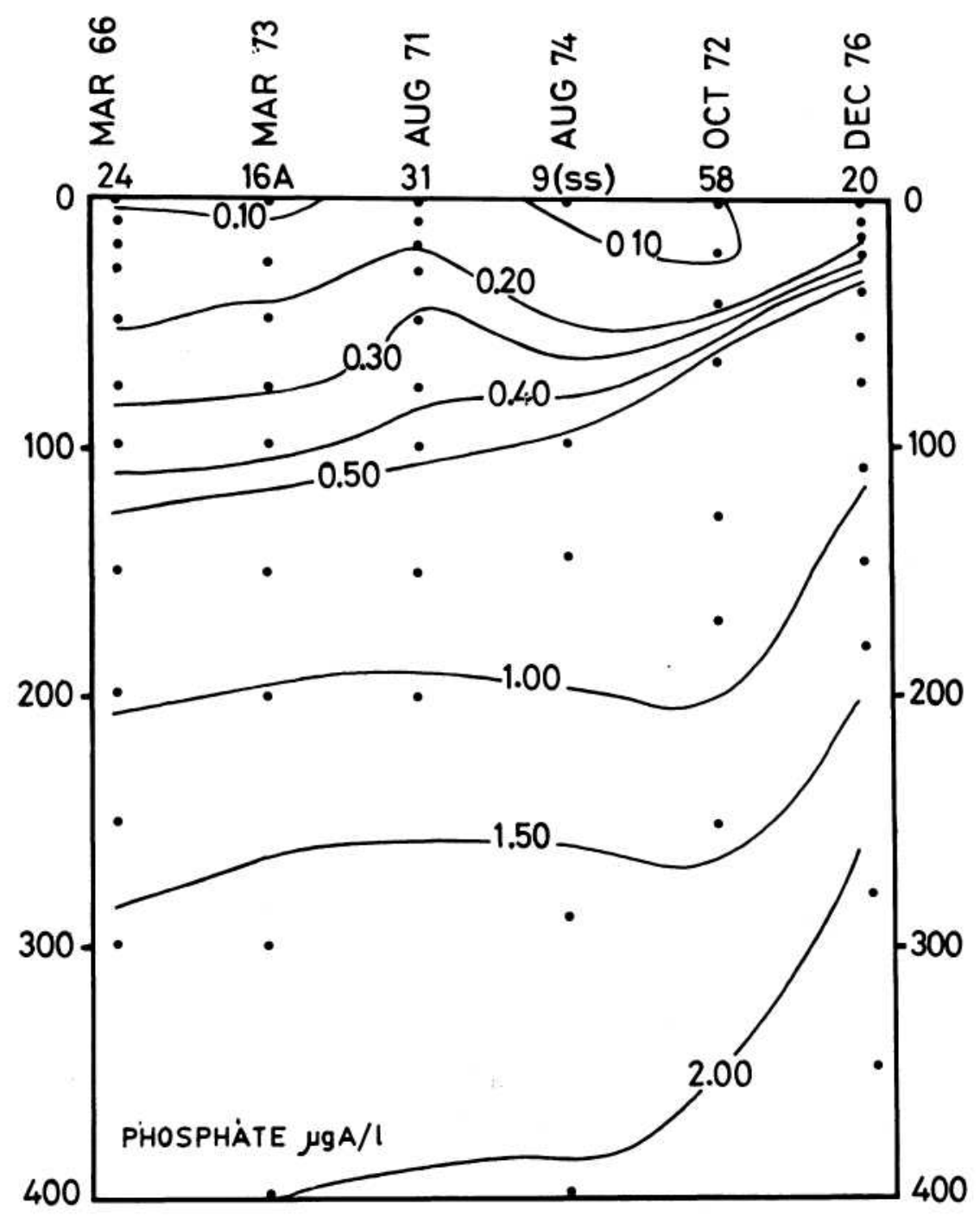

Figure 7. Cross section of inorganic phosphate in the Southern Makassar Strait. Legend is as in Figure 3. 


\section{PRODUCTIVITY OF MAKASSAR STRAIT}

characterized by the $24.0-25.0$ sigma- $\mathrm{T}, 3.0-3.5 \mathrm{ml} / 1$ of oxygen and $0.5-1.0 \mu \mathrm{gA} / 1$ of phosphate. The Intermediate Water, apart from having a salinity minimum, has a density of about 26,8 , an oxygen content of less than $2.1 \mathrm{ml} / 1$ and a phosphate concentration of about $2.0 \mu \mathrm{gA} / 1$ (Fig. 5, 6, and 7).

\section{b. Horizontal distribution}

During the upwelling period (August 1974), a water type of East Kalimantan origin is found at the surface layer, southeast of Laut Island. It has a high temperature $\left(28.4-28.6^{\circ} \mathrm{C}\right)$. a low salinity $(33.8-34.0 \%$ o), a relatively low dissolved oxygen content $(4.35-4.40 \mathrm{ml} / \mathrm{I})$, a very high phosphate $(0.3-0.6 \mu \mathrm{gA} / 1)$, a low nitrate (less than $0.3 \mu \mathrm{gA} / \mathrm{l})$ and a high silicate concentration $(1.0-3.0 \mu \mathrm{gA} / 1)$. Along the South Sulawesi coast, another coastal water of high temperature $\left(28.6-29.0^{\circ} \mathrm{C}\right)$, low salinity (33.6 - $33.8 \%$ ), very high oxygen (around $1.50 \mathrm{ml} / 1)$, high phosphate $(0.3$ - $0.5 \mu \mathrm{A} / \mathrm{l}$ low nitrate $(0.30 .5 \mu \mathrm{gA} / 1)$ and high silicate $(1.0-3.0 \mu \mathrm{g}$ A/1) is present. These two water types overshadow the up welled water which is usually found off the South Sulawesi coast during this period. The occurence of that upwelling at this layer is indicated only by high salinity (34.0 - $34.4 \%$ ), and especially by high nitrate $(0.5-1.0 \mu \mathrm{gA} / 1)$. Contrary to what is expected, its oxygen remains high (around $4.40 \mathrm{ml}$ ), phosphate low (less than $0.1 \mu \mathrm{gA} / 1$. and silicate low (less than $1.0 \mu \mathrm{gA} / 1$ ) (Fig. 8).

At the subsurface layer ( $25-50 \mathrm{~m}$ ), the occurrence of upwelling is further indicated by low temperature (less than $26.5^{\circ} \mathrm{C}$ ), and also by high salinity (34.3 - $34.4 \%$ ) and high nitrate $(1.0-2.0 \mu \mathrm{gA} / 1)$. The Kalimantan Coastal Water at this layer is again indicated by a relatively higher temperature $\left(27.0-28.0^{\circ} \mathrm{C}\right.$ ), low salinity (less than $34.0 \%$ ), low oxygen (less than 4.0 $\mathrm{ml} / 1)$, very high phosphate $(0.6-0.8 \mu \mathrm{gA} / \mathrm{l})$, low nitrate (less than 0.5 $\mu \mathrm{gA} / 1)$ and high silicate $(2.0-4.0 \mu \mathrm{gA} / 1)$. The Sulawesi Coastal Water is indicated by high temperature $\left(27.0-27.5^{\circ} \mathrm{C}\right)$, slightly low salinity (less than $34.3 \%$ o), high oxygen $(4.34 .4 \mathrm{ml} / 1)$, high phosphate $(0.4-$ $0.6 \mu \mathrm{gA} / \mathrm{l})$, low nitrate (less than $0.5 \mu \mathrm{gA} / \mathrm{l})$ and slightly high silicate $(2.0-$ $2.5 \mu \mathrm{gA} / 1$ ) (Fig. 9). A summary of the water types present and their hydrological properties is given in Table II. Based on the horizontal distribution of these properties, the approximate geographical location of the water types is constructed (Fig. 13).

During the pre-upwelling period (May 1975), a water type of the Jawa Sea origin occupies the western part of the Southern Makassar Strait. At the surface layer it is indicated by high temperature $\left(29.2-29.8^{\circ} \mathrm{C}\right)$, low salinity $(31.0-32.5 \%$ ), relatively low oxygen $(4.20-4.25 \mathrm{ml} / 1)$, very high phosphate $(0.5-0.8 \mu \mathrm{gA} / 1)$, low nitrate $(0.4-0.5 \mu \mathrm{gA} / 1)$, and 
A. G. Ilahude

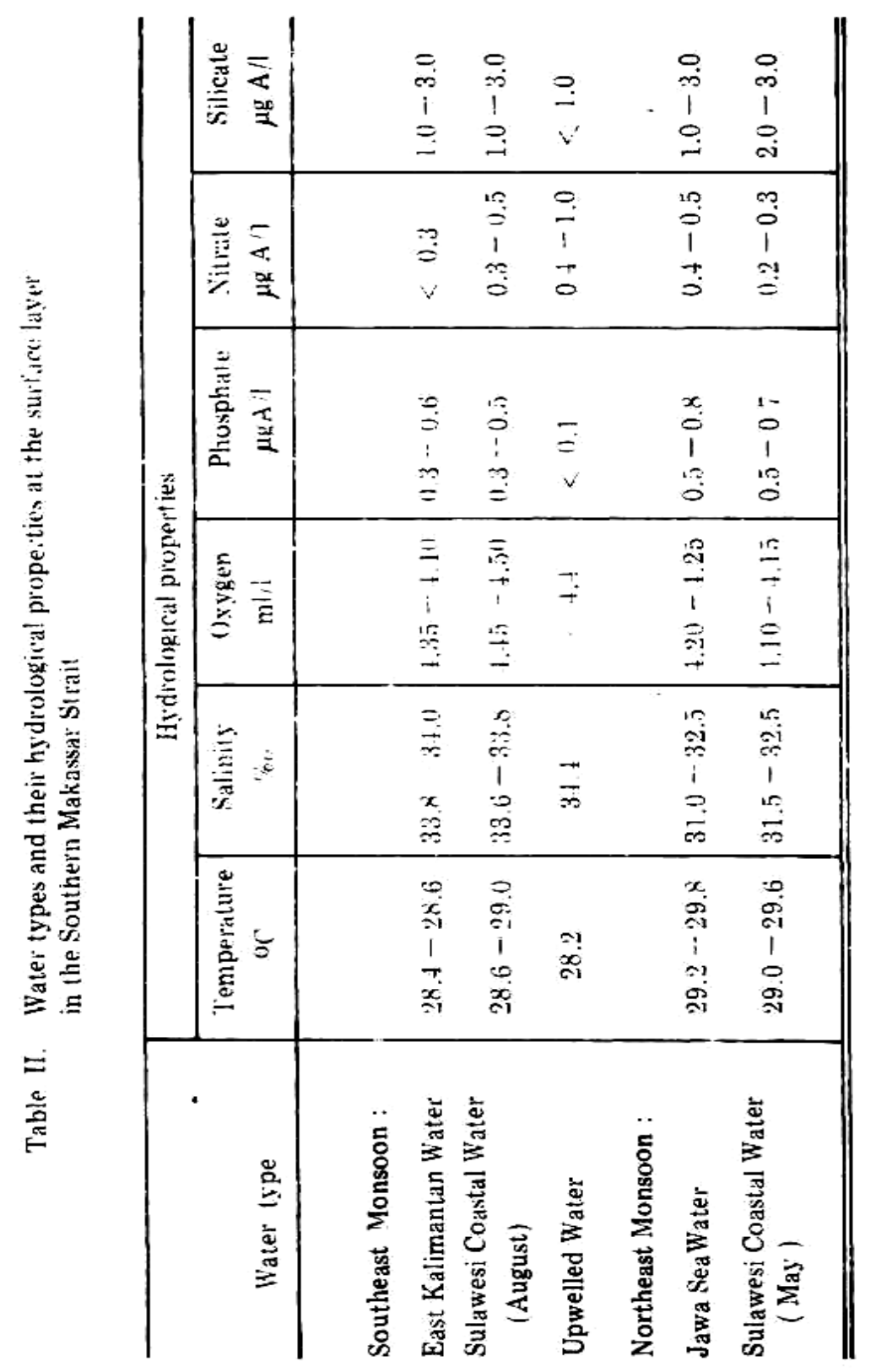




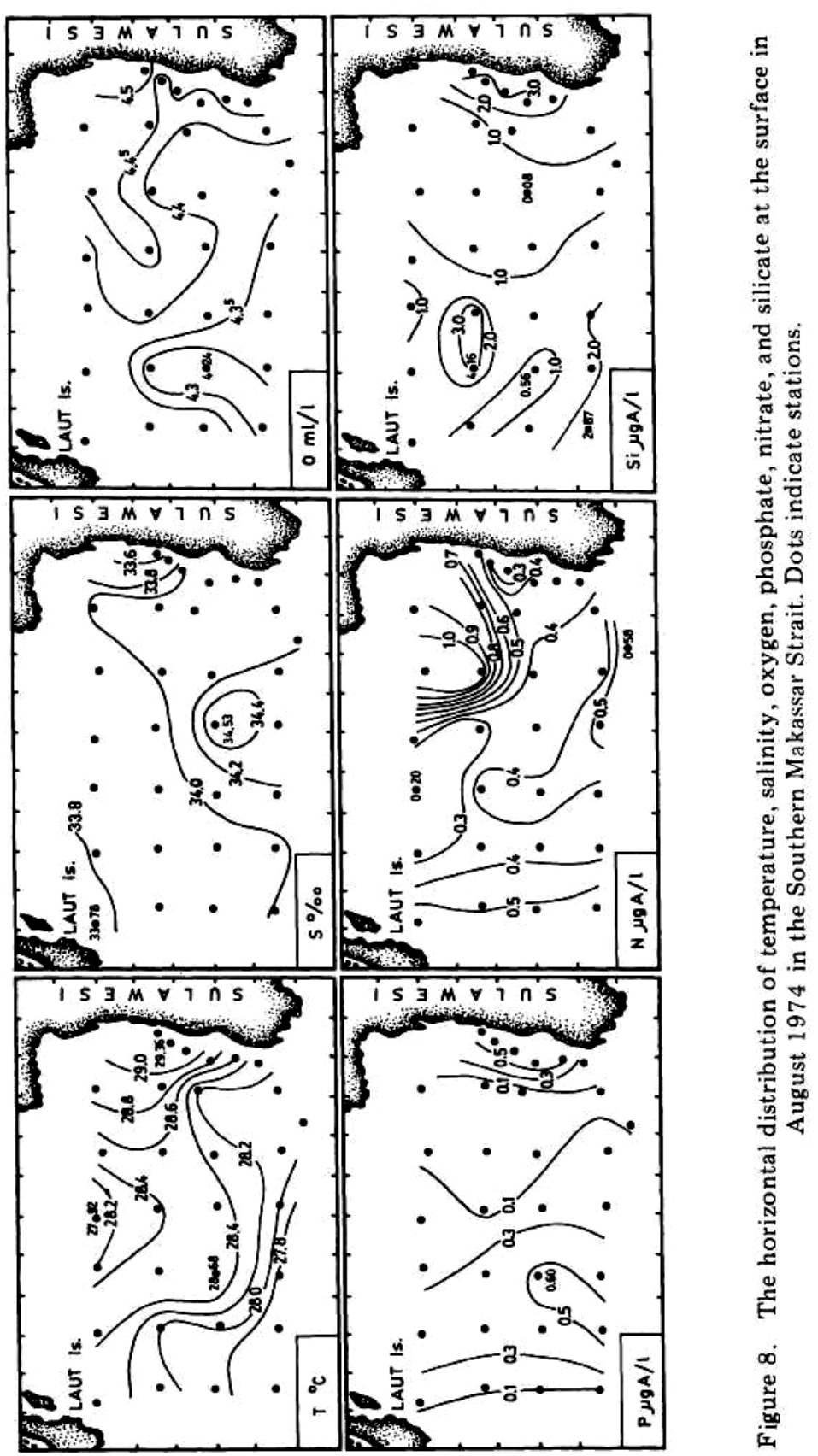




\section{A. G. Ilahude}

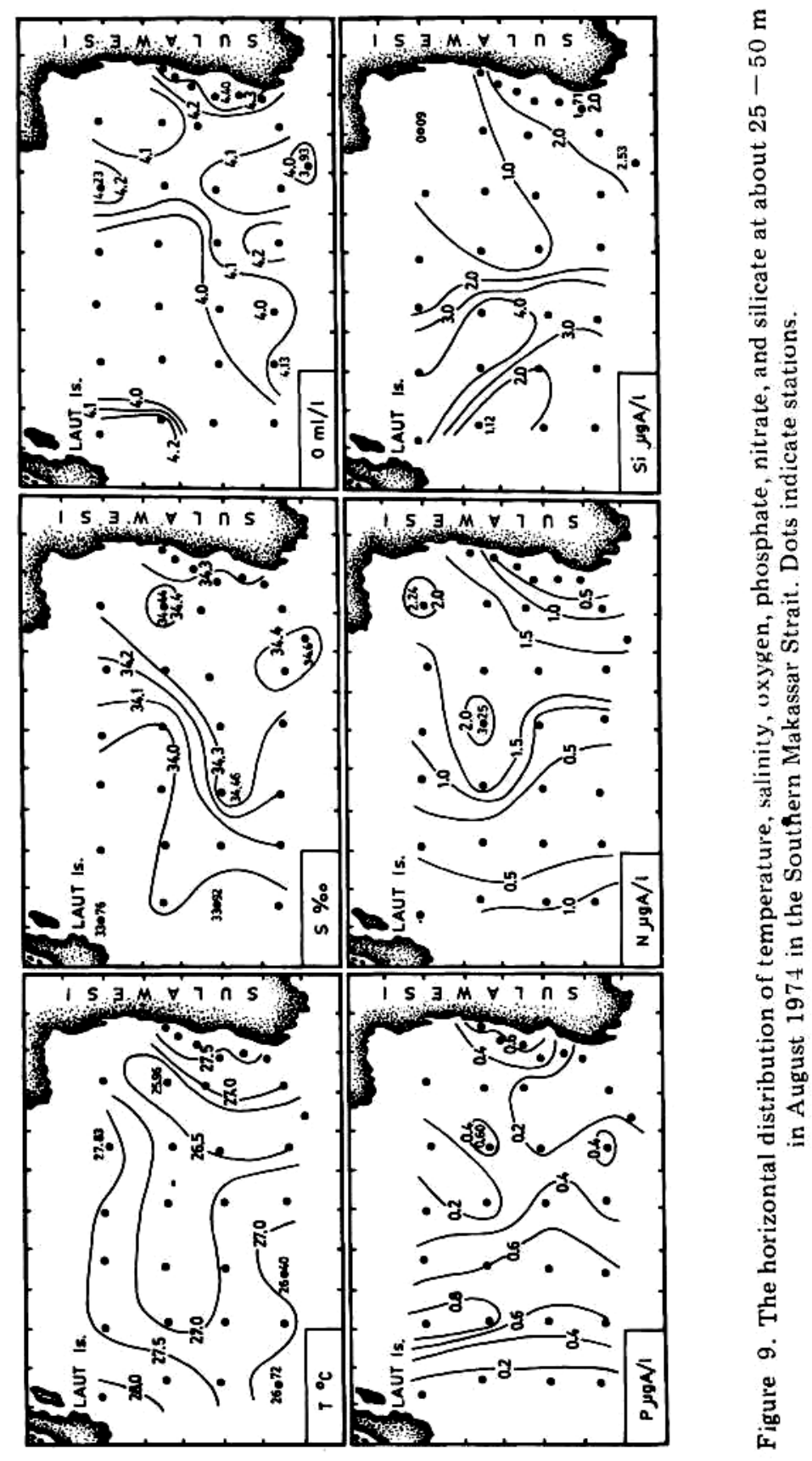




\section{PRODUCTIVITY OF MAKASSAR STRAIT}

high silicate (1.0 - $3.0 \mu \mathrm{gA} / 1)$ (Fig. 10). Except for the very low oxygen $(4.10-4.15 \mathrm{ml} / 1)$ and low nitrate $(0.2-0.3 \mu \mathrm{gA} / 1)$ the Sulawesi Coastal Water at this time of year has temperature $\left(29.0-29.6^{\circ} \mathrm{C}\right)$, salinity $(31.5-$ $32.5 \%)$, phosphate $(0.5-0.7 \mu \mathrm{gA} / 1)$ and silicate $(2.0-3.0 \mu \mathrm{gA} / 1)$ similar to those of the Jawa Sea Water (Table II).

At the subsurface layer $(25-50 \mathrm{~m})$ both water types are indicated by temperature of around $28.0^{\circ} \mathrm{C}$, salinity below $33.5 \%$, oxygen below $3.80 \mathrm{ml} / 1$, phosphate above $0.6 \mathrm{j}$.igA/1 and silicate above $2.0 \mu \mathrm{g} \mathrm{A} / 1$ (Fig. 11). They differ only in regard to nitrate, for which the Jawa Sea Water's values of $1.0-3.0 \mu \mathrm{gA} / 1$ are higher than those of Sulawesi Coastal Water (less than $1.0 \mu \mathrm{gA} / 1$ ). The geographical position of each water type is shown in Fig. 13 and their hydrological properties are summerized in Table 11.

\section{DISCUSSION}

The result of the observation on the monitoring station indicate that during the southeast monsoon (August) up welling occurs regularly in this region. Upwelled water causes high salinity, low temperature, high density, low oxygen and relatively high phosphate particularly at the lower boundary of the homogeneous layer. At its upper boundary (surface layer proper) the effect of upwelling is not so clear. It seems that this condition depends very much on the strength or intensity of the upwelling, a fact that is also pointed out by ILAHUDE (1970).

The thermocline layer is occupied by the Northern Pacific Subtropical Lower Water with its core of salinity maximum at $170 \mathrm{~m}$. The cold water sphere immediately below it is occupied by the Northern Pacific Intermediate Water with core layer of salinity minimum at $400 \mathrm{~m}$ (Fig. 4). Both of these water types are always present in the Southern Makassar Strait. They originate from the Northern Pacific Ocean and enter the region through the Sulawesi Sea. Earlier reports have discussed their distribution in this region (ILAHUDE 1970, POSTMA 1958, and WYRTKI 1961).

The result of the two cruises of the R.V. Samudera in August 1974 and May 1975 reveals some additional information regarding the distribution of surface water types and the productivity of the Southern Makassar Strait. As mentioned earlier, the influence of upwelling on the surface layer is not yet felt in August 1974. Instead the influence of the East Kalimantan Coastal Water and the South Sulawesi Coastal Water is strongly dominant.

The East Kalimantan Coastal Water is so named because it is believed that it comes from East Kalimantan. Examination of the surface salinity distribution for August, reported by earlier workers (HARDENBERG \& SOERIAATMADJA 1975, ILAHUDE 1970, and VEEN 1953) reveals 


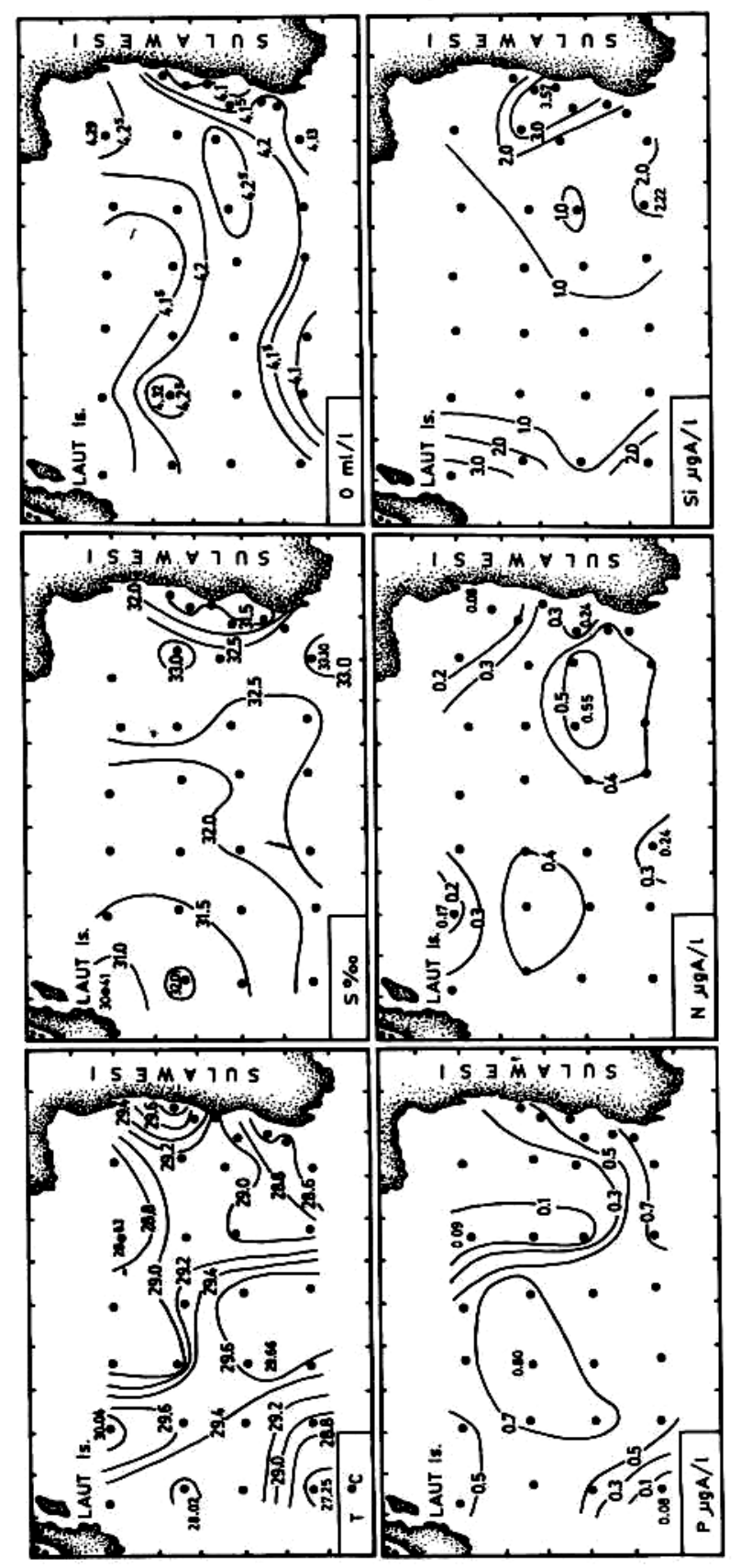

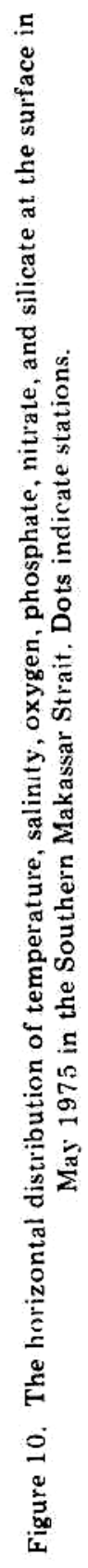


PRODUCTIVITY OF MAKASSAR STRAIT

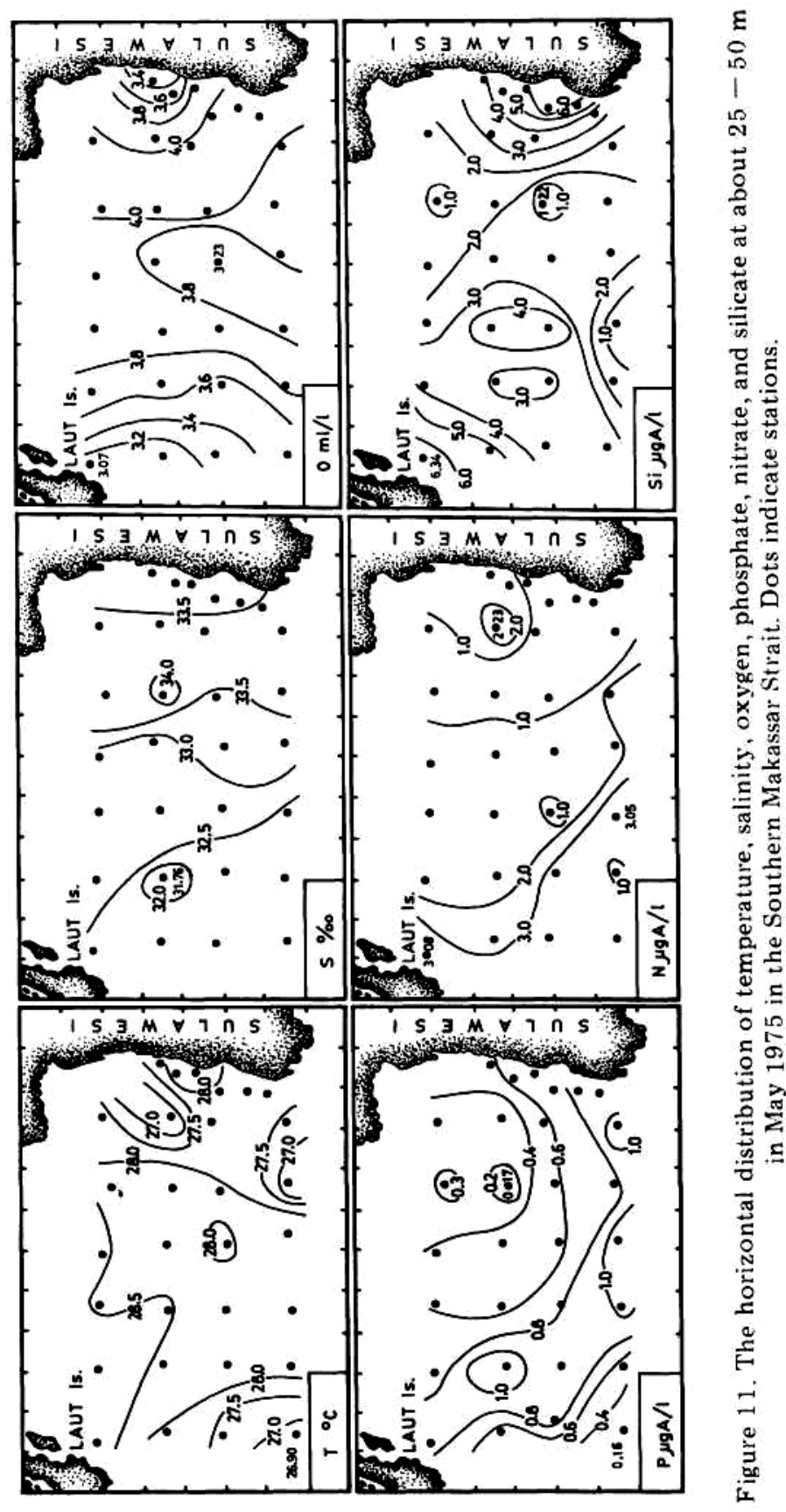




\section{A. G. ILAHUDE}

that a water type of low salinity of $33.5-34.0 \%$ is usually found southeast of Laut Island.

The current in this area at this time of year (April to August) is in general directed to the southwest and west, bringing water from the Northern Makassar Strait into the Jawa Sea (WYRTKI 1961). SJARIF (1959), citing the information contained in the Eastern Archipelago Pilot, reported that during the southeast monsoon, from April to October, the current runs northward along the whole of the east coast of Kalimantan as far as Tanjung Mangkalihat, where it turns southeastward and southward to join the general south-going current of the Makassar Strait. The general flow depicted by the current chart of WYRTKI (1961) for this region during October is in agreement with this interpretation.

In both cases, however, it can be assumed that a water type of low salinity, high phosphate and high silicate, formed in East Kalimantan coastal area, particularly in front of the River Mahakam may eventually be brought to the region by these currents. Meteorological data indicate that relatively heavy rains were recorded in East Kalimantan area for the year 1973 and early part of 1974, preceding August 1974 (Fig. 14). It is believed that the mixing of this fresh water with sea water that forms the East Kalimantan Coastal Water and gives it its low salinity and high silicate. A similar rainfall record was also obtained for South Sulawesi (Fig. 14) which forms the Sulawesi Coastal Water. It has been pointed out that the two water types have quite high concentration of phosphate and silicate (Table II), far above those in the upwelling region. High silicate has been found to characterize the coastal water of the Natuna Sea (South China Sea), Seribu Islands and Jakarta Bay (ILAHUDE, et. al., 1975).

In May 1975 the influence of the Jawa Sea Water in the productivity of the region is also strong. This water type bring high phosphate, high nitrate and high silicate to the Southern Makassar Strait. Along the South Sulawesi coast a water type of similar high productivity is also observed. From the work of BERLAGE (1927), EMERY et. al. (1972), HARDENBERG \& SOERIAATMADJA (1955), SJARIF (1959), SOERIAATMADJA (1956), van WEEL (1923), WYRTKI (1955) and others, it can be concluded that the Jawa Sea Water is highly diluted by fresh water from the Barito and other rivers in South Kalimantan. Precipitation data indicate that the years of 1973 and 1974, preceding May 1975, are the time during which high rainfall values were also recorded for this area (Fig. 14). It is also plausible to suppose that the Jawa Sea Water in the region of Makassar Strait may consist in part of the East Kalimantan Coastal Water.

The normal ratio between nitrate and phosphate in the deeper waters of the ocean, expressed in jugA/1, is $\mathrm{N}: \mathrm{P}=15: 1$. This ratio is also assumed to be valid for the deeper waters in east Indonesia. Table II shows that in the surface water, the ratio is much lower ( $1: 1$ or perhaps $2: 1)$ except 
PRODUCTIVITY OF MAKASSAR STRAIT

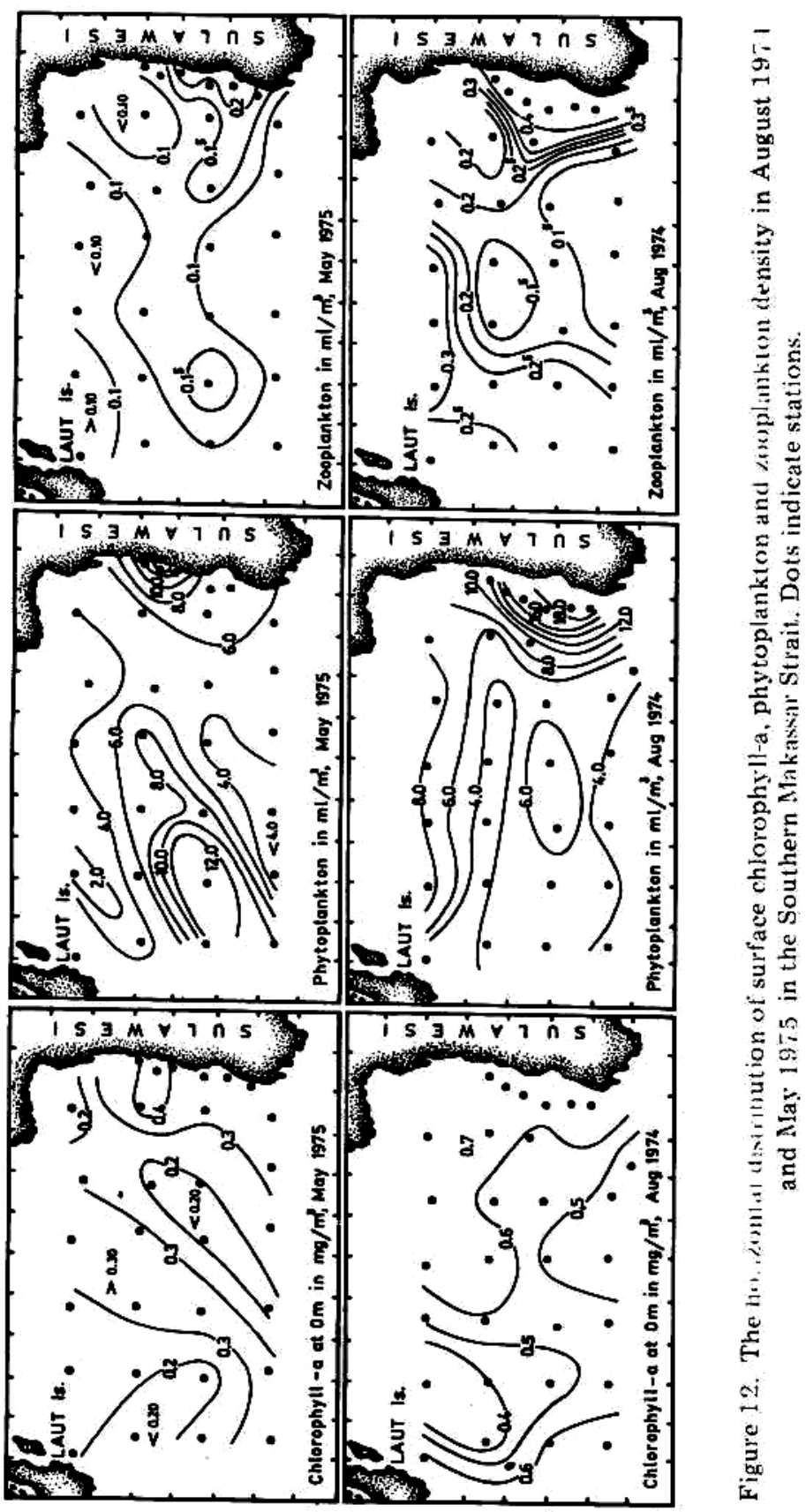




\section{A. G. ILAHUDE}

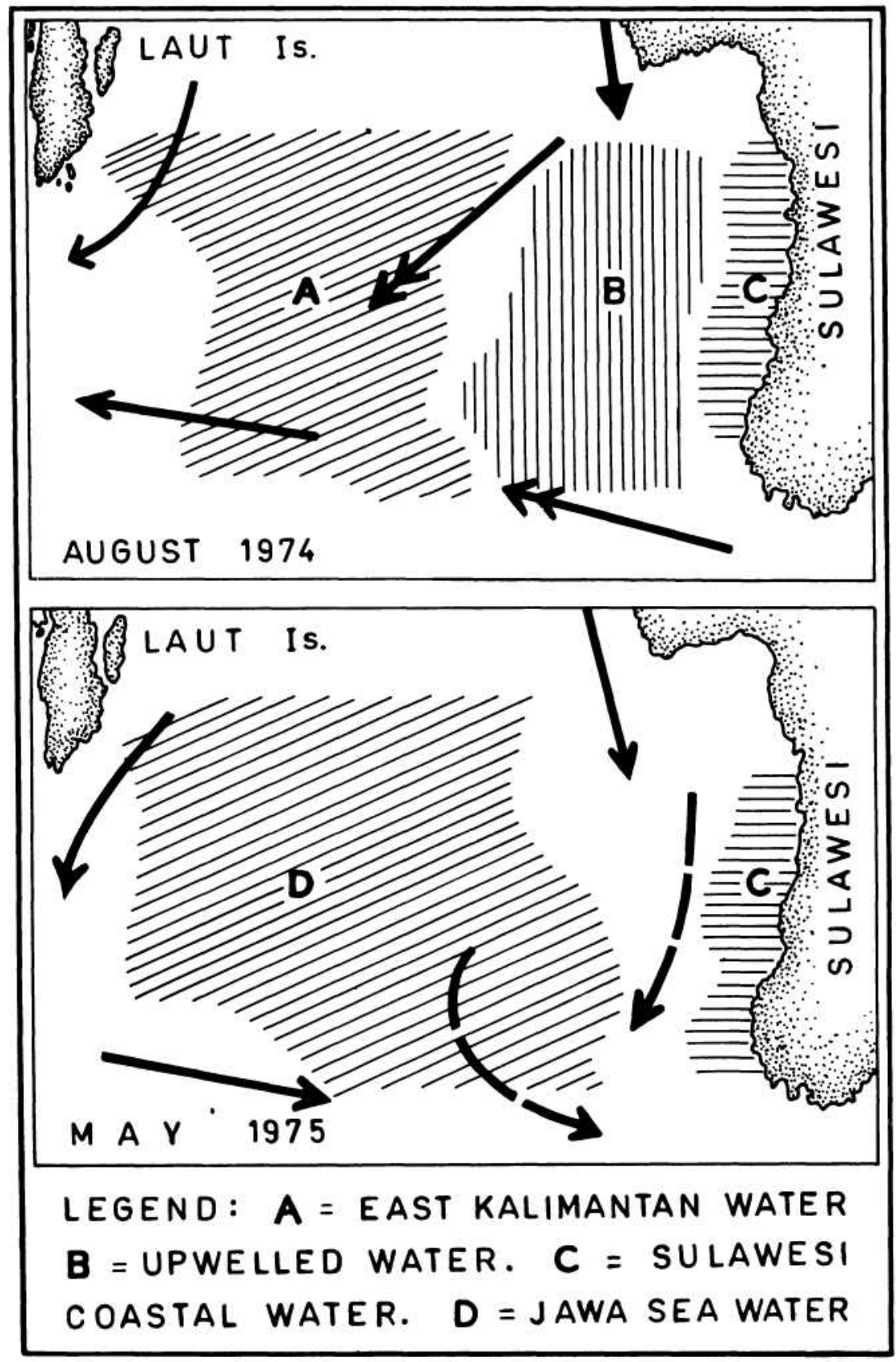

figure 13 . The approximate geographical location of surface water types in the Southern Makassar Strait. The arrows indicate the general direction of currents, redrawn from WYRTKI (1961). 


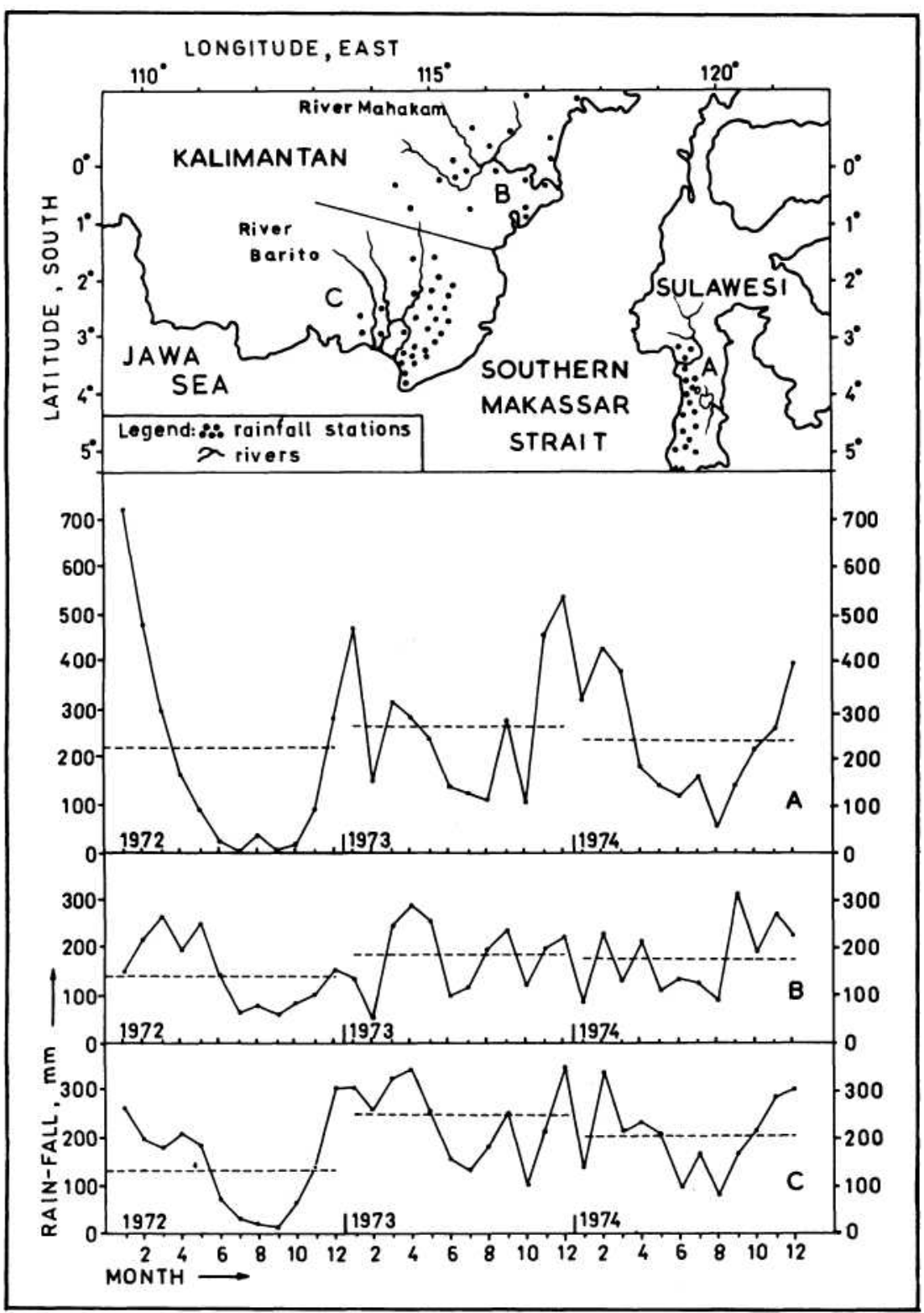

Figure 14. Monthly average (solid line) and yearly average (dashed line) of rainfall in the coastal area of South Sulawesi (A), River Mahakam system, East Kalimantan (B) River Barito system, South Kalimantan (C). Data are obtained through the courtesy of the Meteorological and Geophysical Center, Jakarta. 


\section{A. G. ILAHUDE}

in the upwelled water, where the ratio is $10: 1$ or more. This is under standable since the upwelled water is derived from the deep waters. The $\mathrm{N}$ : P ratio may therefore be a good indicator for the rate of upwelling.

Phytoplankton consumes nitrogen and phosphate in the ratio $15: 1$. The surface values in Table 11 show that in the surface layers nitrogen is depleted more rapidly than phosphorus, possibly due to a more rapid biological turn-over of phosphorus than of nitrogen. Another possibility is the influence of rivers waters on the $\mathrm{N}$ : $\mathrm{P}$ ratio of the low salinity coastal waters, since the rivers may contain relatively high amounts of phosphate. This should be checked by measurements in the rivers themselves.

Plankton and chlorophyll distributions also indicate the influence of both upwelling and coastal drainage on the productivity of the Southern Makassar Strait. The concentration of chlorophyll-a during the upwelling period of August 1974 is 0.4 to $0.7 \mathrm{mg} / \mathrm{m}^{3}$. It is higher than that during the preupwelling period of May 1975 which is $0.2-0.4 \mathrm{mg} / \mathrm{m}^{3}$. The phytoplankton density is 4.0 to $18.0 \mathrm{ml} / \mathrm{m}^{3}$ and zooplankton density is 0.15 to 0.40 $\mathrm{ml} / \mathrm{m}^{3}$ in August 1974. These figures are higher than those in May 1975 which are 4.0 to $12.0 \mathrm{ml} / \mathrm{nr}^{*}$ and 0.10 to $0.20 \mathrm{ml} / \mathrm{m}^{3}$ respectively (Fig. 12). This fact indicates the overall effect of upwelling on the productivity of this region.

In addition it is also seen that not only chlorophyll-a, but also the phytoplankton and zooplankton density is always high along the coast of South Sulawesi, the region of Sulawesi Coastal Water. Similarly the Jawa Sea Water in May 1975 has also quite high phyto- and zooplankton density' the values being 10.0 to $12.0 \mathrm{ml} / \mathrm{m}^{3}$ and 0.10 to $0.15 \mathrm{ml} / \mathrm{in}^{3}$ respectively. The East Kalimantan Water seems to have originally a phytoplankton density of greater than $8.0 \mathrm{ml} / \mathrm{m}^{3}$ and a zooplankton density of greater than $0.30 \mathrm{ml} / \mathrm{m}^{4}$. If this is the case, then it is also a water type of high productivity.

Thus the present study indicates that, apart from upwelling, land mass effect in the form of river drainage from Kalimantan and Sulawesi is also important in governing the productivity of the Southern Makassar Strait. The region does not only undergo enrichment in the southeast monsoon, but to some extent also in the northwest monsoon. This condition seems to make the region relatively more fertile than other Indonesian waters, where enrichment is produced merely by upwelling (Table III).

\section{CONCLUSION}

The study points out that upwelling is not the only factor governing the productivity of the Southern Makassar Strait. Equally important is the enrichment brought about by the presence of different coastal waters in the region. 
PRODUCTIVITY OF MAKASSAR STRAIT

\begin{tabular}{|c|c|c|c|c|c|}
\hline 蒫 & 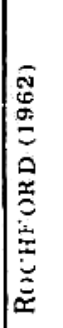 & 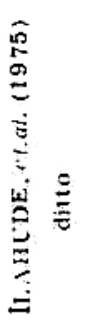 & و & 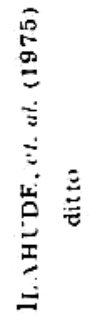 & 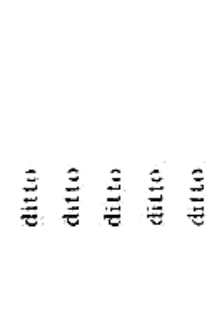 \\
\hline 焉 & 1 & 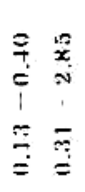 & 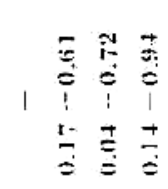 & 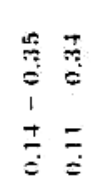 & 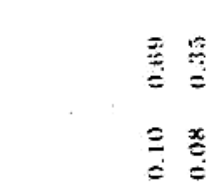 \\
\hline 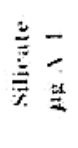 & & $\begin{array}{l}\bar{y} \\
\overline{1} \\
\overline{1}\end{array}$ & 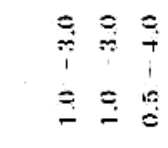 & $\begin{array}{ll}0 & 0 \\
\vdots & 1 \\
\vdots & 0 \\
: & 9\end{array}$ & 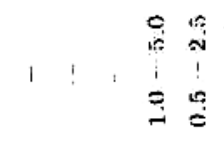 \\
\hline 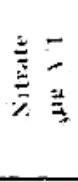 & & 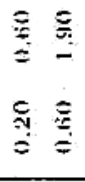 & 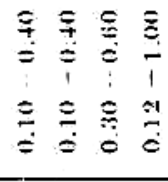 & 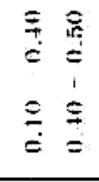 & 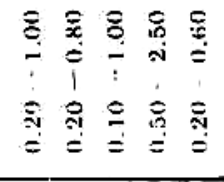 \\
\hline 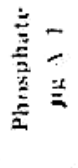 & 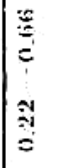 & 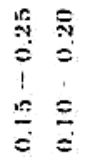 & 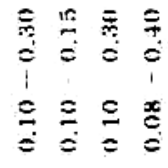 & 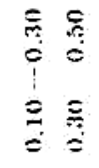 & 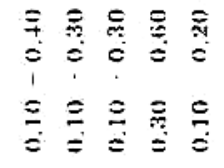 \\
\hline 竞 & $\begin{array}{l}* \\
\vec{n} \\
\vec{z} \\
z \\
\vec{z}\end{array}$ & 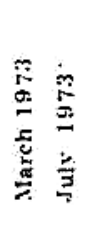 & 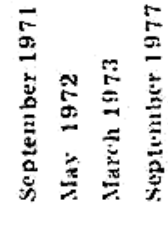 & 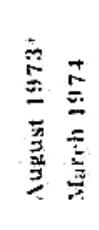 & 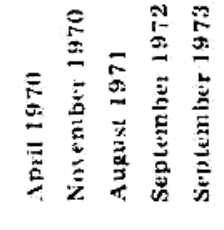 \\
\hline $\begin{array}{l}5 \\
0 \\
0 \\
i \\
x\end{array}$ & 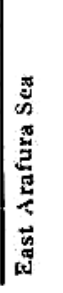 & 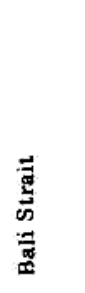 & 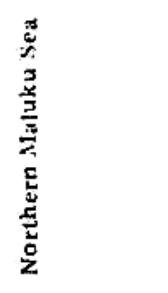 & 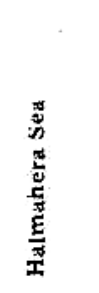 & 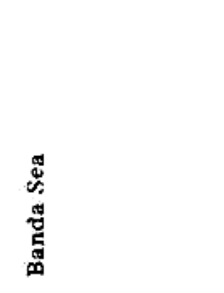 \\
\hline
\end{tabular}




\section{A. G.ILAHUDE}

During the southeast monsoon the enrichment of the surface layer is attributed to the East Kalimantan Coastal Water, South Sulawesi Coastal Water and upwelling. During the northwest monsoon the enrichment is caused by the Jawa Sea Water and the South Sulawesi Coastal Water. The study indicates, therefore, that any change or modification on the fresh water budget in East Kalimantan, South Kalimantan and South Sulawesi will have* a profound effect on the productivity of the region.

\section{ACKNOWLEDGEMENT}

Sincerest thanks are extended to Dr. APRILANI SOEGIARTO and Mr. SUJATNO BIROWO of the Lembaga Oseanologi Nasional, Jakarta, to Dr. KUSWATA KARTAWINATA of the Lembaga Biologi Nasional, Bogor, and to Dr. HENDRIK POSTMA of the Netherlands Institute of Sea Research, Texel-Holland, for reading the manuscript and for the helpful comments. Great appreciation is also extended to Messrs. ANUGERAH NONTJI, DJOKO P. PRASENO and OKTO H. ARINARDI, colleagues at the Plankton and Productivity Laboratories, Lembaga Oseanologi Nasional, for their cooperation in carrying out oceanographical work during the cruises and to Mr. H.L.W. LONDT, commander of the R.V. Samudera and his crew, for the good cooperation in executing the observations in the Makassar Strait.

\section{REFERENCES}

Berlage, H.P. 1927. Monsoon-currents in the Jawa Sea and its entrances. Koniu. Magnet. Met. Observat. te Butaviu. Verhandelingen 19: $1-28,61$ charts.

BIROWO, S. and A.G. ILAHUDE (in press). On the upwelling of the Eastern Indonesian Waters. Paper presented at the 13th Pacific Science Congress, Vancouver, Canada, August 1975.

BRODIE, J.W. 1976. Report on mission as consultant in marine science research at Jakarta, 19 November 1975 - 7 July 1976 (Unpublished Report).

Emery , K.O., E. UChUPI, J. Sunderland, H.L. Uktolseja and E.M. Young. 1972. Geological structure and some water characteristics of the Jawa Sea and adjacent continental shelf. UN ECAFE. COOP Technical Bull. 6: $197-223$.

HARDEN BERG, J.D.F. and R.E. SOERIAATMADJA 1955. Monthly mean salinities in the Indonesian Archipelago and adjacent water for the months : March 1950 - February 1953. Org. Sci. Res. Indonesia, Bull. $21: 1-68$.

ILAHUDE, A.G. 1970. On the occurrence of upwelling in the Southern Makassar Strait. Mar Res. Indonesia 10: 3 - 53 .

-------1971. Oceanographic Station List 1963 - 1966. Inst. Mar. Res., Oceanogr.

Cruise Rep., Special Issue: 1 - 67.

1975. Seasonal features of the hydrology of the Bali Strait. Mar. Res. Indone sia 15: $37-73$.

-----, D.P. Praseno, O.H. Arinardi and A. NontJi. 1975. Peta oceanografi hasil pelayaran selama PELITA I (1969 - 1974) (Oceanographical charts as the results 


\section{PRODUCTIVITY OF MAKASSAR STRAIY}

of the Five Year Plan (1969 - 1974). In: A. Soegiarto and S. Birowo (eds.). Atlas Os eanologi Perairan Indonesia dan Sekitarnya 2: 1 - 32, 483 charts.

INST. MAR. RES. 1971. Hydrological and plankton observations in the Seribu Islands, Banda Sea and Maluku Sea. Occanogr. Cruise Rep. $5: 1-64$.

----- 1973a. Hydrological, plankton and pigment observations in the Seram Sea, Piru Bay and the Banda Sea. Oceanogr. Cruise Rep. 10:1-81.

1973b. Hydrological, plankton and pigment observations in the Maluku Sea and in the Bali Strait. Occanogr. Cruise Rep. $11: 1-38$.

----- 1974. Hydrological, plankton and pigment observations in the Makassar Strait, Madura Strait and Eastern Jawa Sea. Oceanogr. Cruise Rep. $15: 1-52$.

1975. Hydrological, plankton and pigment observations in the Makassar Strait, Madura Strait and Eastern Jawa Sea. Oceanogr. Cruise Rep. 16:1-48.

------ 1976. Hydrological, plankton and pigment observations in the Gulf of Bone and in the Flores Sea. Oceanogr. Cruise Rep. 21 : $1-65$.

------- in press. Hydrological, plankton and pigment observations in the Sulawesi and Maluku Seas. Oceanogr. Cruise Rep., 23.

NONTJI, A. 197 5. Distribution of chlorophyll-a in the Banda Sea at the end of up-welling season. Mar. Res. Indonesia 14 : 49 -- 59.

Postma, H. 1958. The chemical results and a survey of water types and currents. The Snellius Exp. 11(8) : 1 - 116.

Rochforu, D.J. 1962. Hydrology of the Indian Ocean. II. The surface waters of the southeast Indian Ocean and Arafura Sea in the spring and summer. Ausir. J. Mar. Freshw. Res. 1 3(3) : $226-251$.

SJARIF, S. 1959. Seasonal fluctuation in the surface salinity along the coast of the southern part of Kalimantan (Borneo). Mar. Res. Indonesia $4: 1-25$.

SoERIAATMADJA, R.E. 1956. Seasonal fluctuations in the surface salinity off North Coast of Jawa. Mar. Res. Indonesia $1: 1-19$.

VEEN. P.Ch. 1953. Preliminary charts of the moan salinity of the Indonesian Archipelago and adjacent waters. Org. Sci. Res. Indonesia Bull. $17: 1-47$.

WEEL, KM. van 1923. Meterological and hydrogeological observations in the western part of the Netherlands East Indian Archipelago. Treubia $4: 1$ - 559.

WYR T K I, K. 1955. Monthly charts of surface salinity in Indonesia and adjacent waters. J. Conseil. Perm. Int. Expl Mer 21 ( 3 ) : 268 - 279.

------ 1961. Physical oceanography of the Southeast Asian Waters. Naga Report 2 : 1 - 195. 